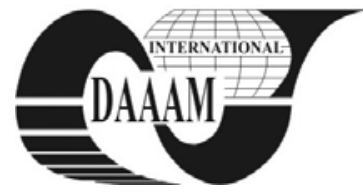

Annals of DAAAM for 2011 \& Proceedings of the 22nd International DAAAM Symposium, Volume 22, No. 1, ISSN $1726-9679$ ISBN 978-3-901509-83-4, Editor B. Katalinic, Published by DAAAM International, Vienna, Austria, EU, 2011 Make Harmony between Technology and Nature, and Your Mind will Fly Free as a Bird

\title{
USE OF ERGONOMICS IN DESIGN SELECTED DEPARTMENT WORKSPACE IN ENGINEERING COMPANY
}

\author{
NAKATOVA, H[enrieta]; HRICOVA, B[eata] \& BADIDA, M[iroslav]
}

\begin{abstract}
A substantial part of the contribution is the description of the technology used at work in the foundry area, the description of a particular molding facility in terms of work location, work area and equipment according to basic ergonomic criteria. It is important to determine the correct working position of workers, work space and work equipment in terms of ergonomic requirements. All the requirements are processed graphically in the program CATIA V5 for foundry work.

Key words: ergonomics, design workspace, working position, working space
\end{abstract}

\section{INTRODUCTION}

This contribution is dedicated to issues related to the use of ergonomics in the design of the selected department in the engineering company. As the reviewed workplaces a workplace was chosen for manual molding operation in foundries

\section{DESIGN OF A WORKPLACE ACCORDING TO ERRGONOMIC CRITERIA}

Designing ergonomically suitable workplace based on principles that take into account the adapting of workplace for each worker and for each work task. The article is a solution to the optimal molding department design (Fig.1).

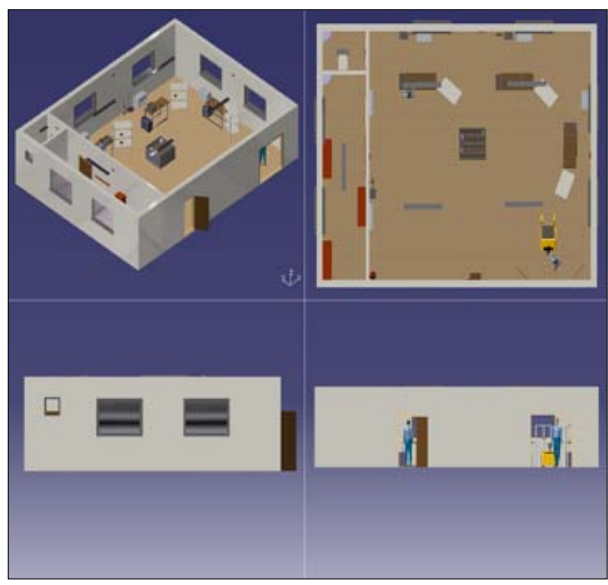

Fig. 1. Proposal of molding workplace in four views

\section{WORKPLACE DESIGN}

The detailed projecting of the workplace deals with:

- How will be the machines placed (work tables) at the workplace

- How will be the auxiliary equipment placed:

$$
\begin{array}{ll}
> & \text { toolboxes } \\
> & \text { racks for fixtures } \\
> & \text { pallets for storing components } \\
> & \text { box for supplies (etc.) }
\end{array}
$$

Since in this case it is a workplace with manual production, it is important to design the workplace with regards to the optimal use of the load on workers.

Workers focus primarily on manipulation with objects related to production - forms, tools and production equipment. It is therefore important to ensure:

- handling the least time consumptipon

- favourable conditions for the work of the workers

- high production quality with the effective utilization of production facilities, resources, materials and energy.

\section{WORKING POSITION}

There are three workers working at the workplace, all of them are working in a standing position. It's not very optimal, since this position causes more burden on the legs, but for the nature of the job this position is essential. As the perfect standing position is considered the position where the curvature of the spine is in the cervical and lumbar area (Fig.2).

Workplace mobility parameters correspond to the hands and feet in all directions and outreach opportunities: (Gilbertova \& Matousek, 2002)

- $\quad$ the requirements for strenght do not exceed the physical capacity of workers

- efficiency of movement is achieved by appropriate technical assistance of support equipment

- movements of the limbs and body are mutually balanced, to avoid one-sided burden on the motion

- labor movements, which place high demands on precision, strength or speed, are concentrated in the area of optimal outreach of both hands

- maintaining long-term static tension of individual muscles is excluded

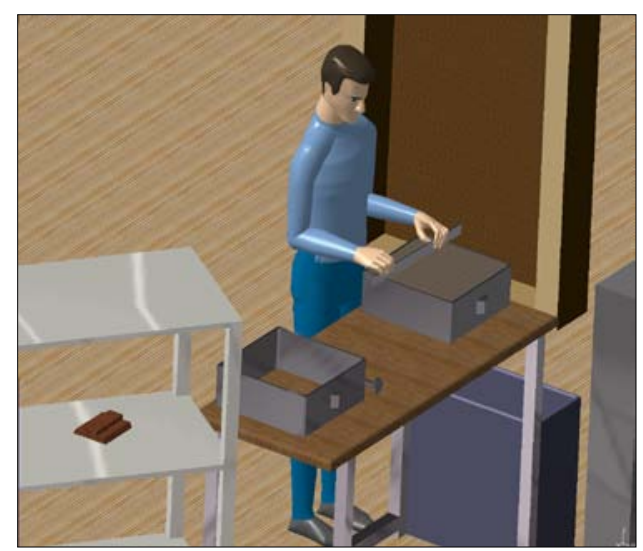

Fig. 2. Working position (standing) 


\section{WORKSPACE}

Jobs are carried out in optimal outreach and handling facilities and job aids and tools are located within an area of outreach. Working table height is $95 \mathrm{~cm}$. According to the vision field the jobs are performed in the optimal and normal visual field (Gilbertova \& Matousek, 2002).

Workspace consists of a table, where the forms are prepared. Compared with the original workplace, I proposed that every worker in his working space rack (Fig. 3), where they are stored job aids and tools as models of components for preparing molds, models inlet system blade and container molding compounds etc. are stored, which ensures that workers have the tools and professional equipment, still located in the vicinity. This considerably shortens the preparation time of the forms.

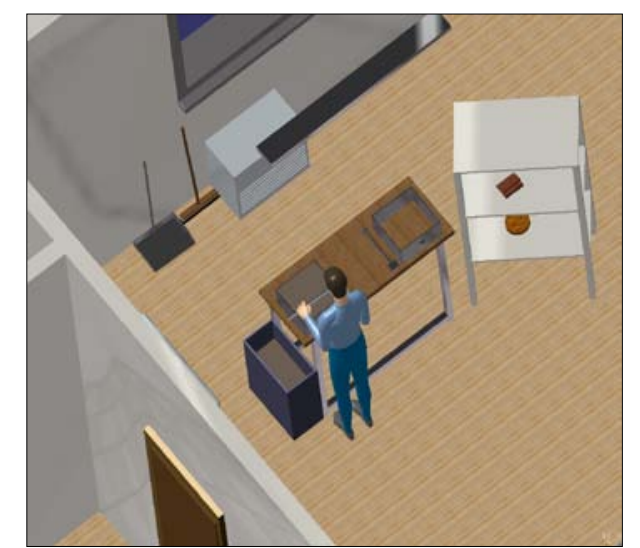

Fig. 3. Workspace for staff

\section{SPECIAL AND AESTHETIC REQUIREMENTS}

External walls are painted slightly tinted yellow. Yellow brightens and brings in atmosphere with tjhe effects of warm sunshine. It effects encouraging and inciting the work performance and with reflectance improves the light conditions at the workplace (Slamková et., 2010). At the workplace there are satifactory facilities for personal hygiene provided. On the west side of the workplace is the wardrobe department located, which is compared to the original locker room equipped with shut-off boxes for each employee workstation and the windows are tinted because of intimacy. Locker room is equipped with a sink with hot and cold running water. In the locker room is situated table and chairs, dressing room also serves as a rest place and cantine as well. Situated next to the locker rooms is a toilet, since there are 3 employees working at the workplace. According to the Act No. 391/2006 of coll. the minimum safety and health requirements for work, one toilet is sufficient for both women and men in the workplace with the number of workers less than five persons.

I propose to use self-leveling poured floor, which is pale brown. This flooring is hygienic, healthy and environmentally friendly, highly resistant to mechanical damage and abrasion. It is difficult to burn, dust free and easy to treat and has a long life.

The layout of the working tables is compared to the original operation located not to obstruct the escape routes (Fig. 4) with regards to the optimal use of the department space. Each worker has its own working tools, job equipment and tools. Also, each worker and his whisk broom to clean up spilled molding compounds.

Box with molding mixtures is centered in the workplace which allowes all workers to have almost the same distance and thus it ensures safe and comfortable handling of molding mixtures. The workplace is also situated with a fire extinguisher and first aid kit.

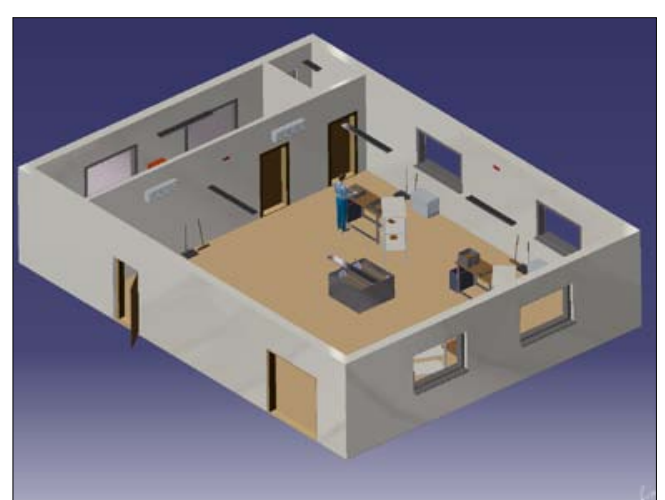

Fig. 4. Workspace design - escape routes

\section{HYGIENE REQUIREMENTS}

Optimal lighting is made up of two components:

natural - northern and eastern wall of the workplace are equipped with adjustable long-distance windows. East and north side offers the use of daylight or sunshine. Therefore, I propose to have glass windows with smoke tinted glass, which has a thickness sufficiently isolating the interior of the workplace from the impact of outside low temperatures.

artificial - consisting of four lamps of which the intensity of illumination ( $E=300 \mathrm{~lx}$ ) for the type of work is sufficient (Hatiar, 2008).

Optimal microclimate is provided using the comprehensive HVAC equipment - air conditioning. Also at every desk is a mounted suction installed for dust particles and small particles of sand mixtures. Recommended air exchange in general foundry is from 4 to 8 times per hour.

\section{CONCLUSION}

Aim of this article was to outline the issues related to ergonomics. In particular, we design foundry in engineering company under the precise ergonomic criteria. By the ergonomic design is expected to achieve maximum performance of workers, productivity, and improve workers safety, staff motivation, which is a benefit for the engineering operation.

\section{ACKNOWLEDGEMENTS}

This paper has been elaborated within the project KEGA 3/7426/09 Creation of didactic details and publishing of university textbook " Physical factors of environment - valuation and assessment" for main field 2nd and 3rd level of study environmental focused studying programs.

\section{REFERENCES}

Chundela, L. (2001). Ergonomie,ČVUT Praha: Grada, 171s. ISBN 80-01-02301-X, Praha

Fabian, M.C (2008). CAD - 3D modelovanie v CATIA V5 (objemy, povrchy, výkresy a aplikácie $v$ praxi),Strojnícka fakulta TU v Košiciach,. 197 s. ISBN 978 - 80 - 553 -0095 -5 ,Košice

Gilbertová, S. \& Matoušek, O. (2002). Ergonomie: optimalizace lidské činnosti, Praha:Grada, . 239s., ISBN 80 - 247 - 0226 - 6,Praha

Slamková,E. \& Dulina, L. \& Tabaková, M.(2010). Ergonómia v priemysle, Žilinská univerzita, ISBN 978-80- 89401-093, Žilina

Hatiar, K. (2008).. Moderná ergonómia. Produktivita a inovácie,Vol.9,No.6.,pp.22-24,ISSN1335-5961 